\title{
TRANSFORMING INEFFECTIVE FEEDBACK OF THE STUDENTS TO EFFECTIVE FEEDBACK: A STUDY ON THE STUDENTS OF ENG091 AND ENG101 OF BIL AT BRAC UNIVERSITY
}

\author{
Mohammad Akteruzzaman ${ }^{1}$, Md. Aftab Uddin Chowdhury ${ }^{2}$ \\ ${ }^{1}$ Lecturer, BRAC Institute of Languages, BRAC University, BANGLADESH, m.akter@bracu.ac.bd \\ ${ }^{2}$ Lecturer, BRAC Institute of Languages, BRAC University, BANGLADESH, aftab@bracu.ac.bd
}

\begin{abstract}
This paper aims at developing the rationale among the learners regarding the significance of peer feedback on a given speech community and any specific context. As for any EFL or ESL context, effective feedback of the peers on speaking can help the students rectify their mistakes regarding the use of English Language in the classroom, this paper holds the traditional characteristic of the peer feedback in the speaking classes as the research problem. Generally, in the English Language classes of ENG101 and ENG091 at BIL, BRAC University, whenever students are asked to provide feedback on their peers' speaking, they are used to providing feedback with certain stereotypical and ineffective comments that do not help the students rectify their mistakes significantly and at the same time, the students who are giving ineffective feedback for their peers cannot utilize their creativity effectively. Keeping that in focus, we will show how ineffective feedback of the peers can successfully turn into effective feedback by the help of the teacher and how the techniques of the effective feedback can make the students utilize their critical thinking as well as help them learn different aspects of speaking strategies ranging from turn taking to deconstruction of ideas and scanning. For this research, data collection has been accomplished by interviews, focused group discussions and questionnaires from the participants and the sets of data were analysed by Multivariate Data Analysis. At last, this paper has some possible speculations that one might encounter while implementing these techniques.
\end{abstract}

Keywords: Peer feedback, critical thinking, T-S interaction, S-S interaction.

\section{INTRODUCTION}

Feedback has always been in the focus as it helps learners to achieve success in a larger scale through rectifying their common errors. At the same time, peer feedback gains utmost importance in terms of improving the students' critical reasoning skills and adopting speaking strategies. Scholars have also evaluated peer review as it can be taken as a formative developmental process from a social and cognitive aspect (Hyland \& Hyland, 2006). Glasson (2009) believes that students react positively to their peer feedback most of the time. Moreover, feedback from peers and from adults may receive different responses 
from the students (Dweck \& Bush, 1976; Henry, Medway, \& Scarbro, 1979). However, peer feedback might not have the same quality as the feedback given by the teacher, still it can be modified through guidance and instructions to prove to be fruitful for the peers (Topping \& Ehly, 1998). Shafaei (2011) asserts that by doing peer feedback, learners can experience diverse roles which might not be there in their regular life or traditional settings. He also believes that it helps learners raise the awareness of their own strengths and weaknesses and thus contribute to collaborative learning. Moreover, while receiving feedback from the peers, students feel less anxious in comparison with receiving feedback from the teacher (Tsui \& M., 2000). (Jacobs, Curtis, Braine, \& Huang, 1998) specify that students are at an ease when peers are assessing them as they are more empathetic, less threatning and less busy than the teacher. For this, it has been considered as an advantageous technique (Mangelsdorf, 1992; Obah, 1993). In our views, we have taken peer feedback as a tool to benefit the learners in a two way process, as a speaker or the receiver of the peer feedback and as a peer feedback provider. Our understanding of the situation shows that through some modifications and proper guidances, ineffective feedback can be transformed into an effective one.

\subsection{Methodological approach to Peer Feedback}

The act of providing peer feedback for our research included three distinct stages. At first, students were asked to provide feedback to their peers as they liked it to be. Later on the feedback was closely observed by the teachers and noted down as samples. Initially these were some stereotypical and ineffective ones. As the last phase, students were instructed again to give feedback based on some techniques discussed in the upcoming part of the paper. As we know that peer feedback can be utilised to encourage discussion between controlled groups and thus verbalize some ways of achieving academic success. In this process, students evaluate the performances of their fellow learners using their own judgment and try to integrate major skills of language learning that can also prove to be beneficial to them from many aspects. It can be fruitful as the students provide feedback for their fellow mates and can be divided into three subparts (Peer feedback, 2014): what has been done well from the viewpoint of success criteria, what still needs to be done in order to achieve the success criteria and advice on how to attain that. During this research, hundred students were selected and based on their responses the whole paper has been designed to draw the conclusion.

\subsubsection{Background of the participants:}

As we are taking the speaking of English language into consideration, the background of the students revolves around the learning of this language, not acquisition. Here, like other countries with ESL context, English is taken as a gateway to academic success and learners have to pass individually in two different categories of English exams. To enter the tertiary level education, students have to come through the layers of Higher-Secondary School Certificate (HSC) centrally arranged by the government. Unfortunately, in most cases, it has been noticed that students are not put through the practices of communicative teaching and they are not provided with the exposure of practicing their speaking skills in English. Even with some exceptions, students typically reverb through the question papers of the last few years for preparing themselves for their HSC exams. As this is becoming a common practice day by day, they linger behind when they are asked to showcase their all four macro skills (Reading, Writing, Speaking and Listening) in English language. To add to this adversity, there are different streams of students in HSC level coming under the same roof of a university. To demarcate some examples, the most common streams are English Medium, Bangla Medium, Bangla Version and Madrasa Education. Although each of them has separate and distinct syllabus and curriculum, it sometimes poses a threat to the teachers of the universities and thus hamper the learning environment. For our concern, making them speak in English has always been the first impediment to overcome as some of them do not prefer to communicate in English, some feel shy while speaking in English and some just do not feel the necessity of English in real life situations. Therefore, we have attempted to make the best use of their speaking by speaking for their peers first. We have observed that they are quite instantaneous and enthusiastic in providing feedback for their peers or receiving it from them.

\subsubsection{Background of the courses of the participants:}

According to the policy made by the University Grants Commission of Bangladesh, all the students have to complete six credits in learning English language during their undergraduate education to ensure the proper exposure to academic writing and real life speaking. In line with this vision, BRAC Institute of Languages (BIL) at BRAC University has designed the English language courses in a way that these courses can be of the utmost benefit for the students. To begin with, ENG091 or Foundation Course in English targets the intermediate level students. Being a non-credit course, this course provides an opportunity for those students who are struggling with their English language skills though they have managed to achieve the expected 
marks in other subjects. In another sense, this course introduces them with the very basic concept of academic writing and oral presentation through different activities like group works, pair works and assignments. On the other hand, ENG101 or English Fundamentals is a three credit course exclusively designed for the upper intermediate level students. It offers them a solid ground to redecorate their notion of using English in both academic and professional contexts (retrieved from www.bil.bracu.ac.bd). In both cases, there are two major wings: Writing \& Reading and Speaking \& Listening. Though BIL offers a lot of other courses like ENG102 (English Composition), ENG202 (Business English), ENG204 (Essentials of Academic Writing) and many other modern language courses, we have selected ENG091 and ENG101 because these two courses take place consecutively one after another which makes it easier to evaluate the progress or keep record and students of these two levels are mostly fighting with improving their skills in English.

\subsubsection{Observation, Data Collection and Data Analysis:}

At the beginning, different types of feedback were collected from the students. Among them, the most recurrent ones have been sorted out for the preparation of data analysis. During the process, fifty students were selected from ENG091 and fifty were taken into consideration from ENG101. As all the speaking presentations are aimed at developing their speaking proficiency, randomly six of them have been chosen to get a reliable set of responses and for this we have selected News Report, Book Reading, Meet the Press, Human Rights, Advertisement and Debate as sample presentations. For all the presentations, students are divided into some groups of five to six in each and they are given a specific time for preparation, normally three to four days. All of these presentations also make them engage themselves into real life situations and make them a better speaker throughout the semester long process. After each presentation, students were asked to provide effective feedback to the presenters and the results have been projected through six different distinct graphs which prove that their feedback is all about giving an overall comment or to some extent, making a casual remark. Obviously, these are not helpful from both the perspectives of the presenter and the person giving the feedback. For the presenter, receiving a peer feedback should be a specific and constructive one which will lead to the rectification of his ideas and the level of competency when he is appearing before an audience for oral presentation. On the other hand, the person who is giving feedback, should use his critical thinking to deconstruct and scan the ideas presented to build his own set of effective feedback. In opposition, the current scenario shows that both the parties are suffering from the same problem which can be solved by using Effective Peer Feedback as denoted by Goldrick-Jones \& Mossman (2014).

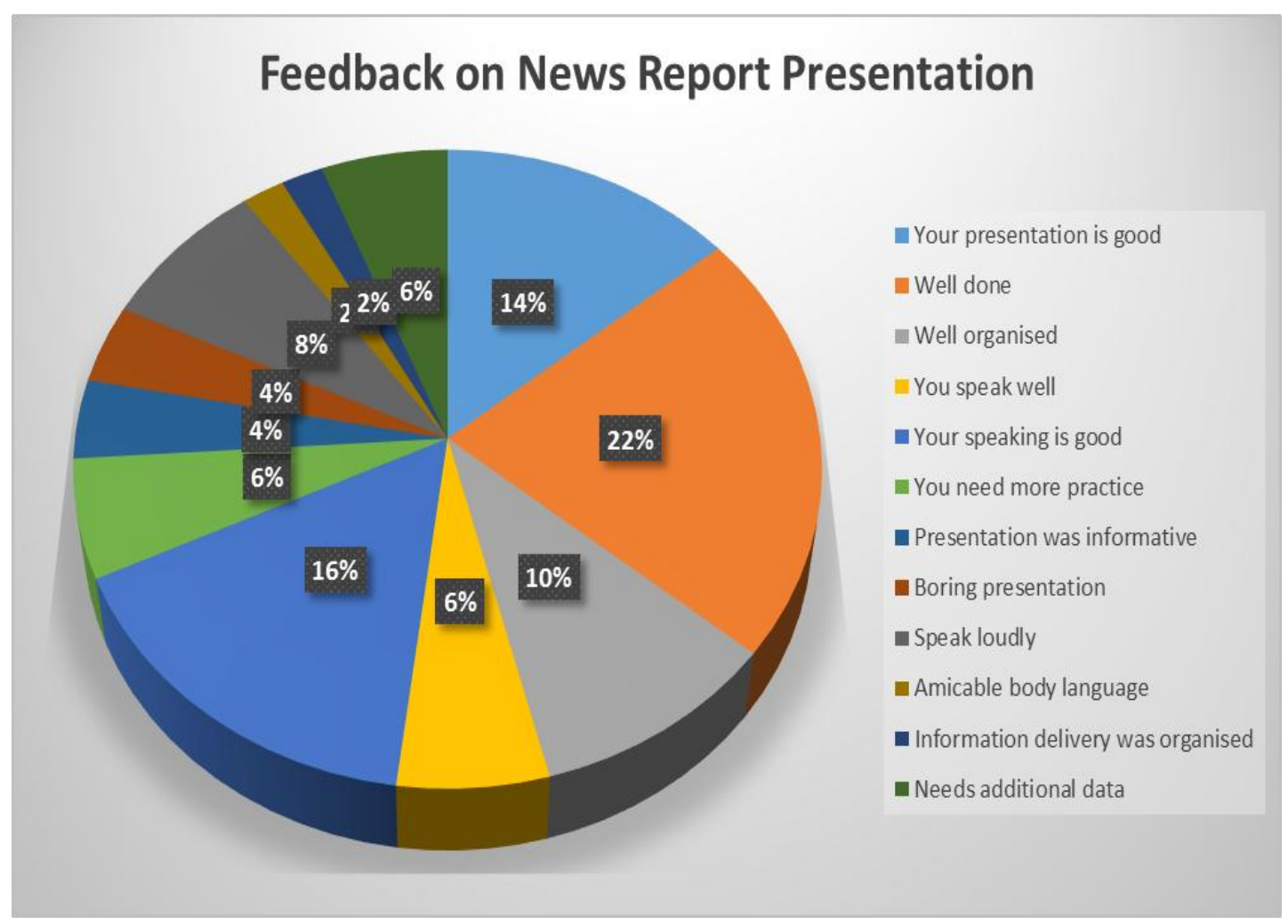

Figure.1: Responses from the students on News Report Presentation 


\section{Feedback on Book Reading Poster Presentation}

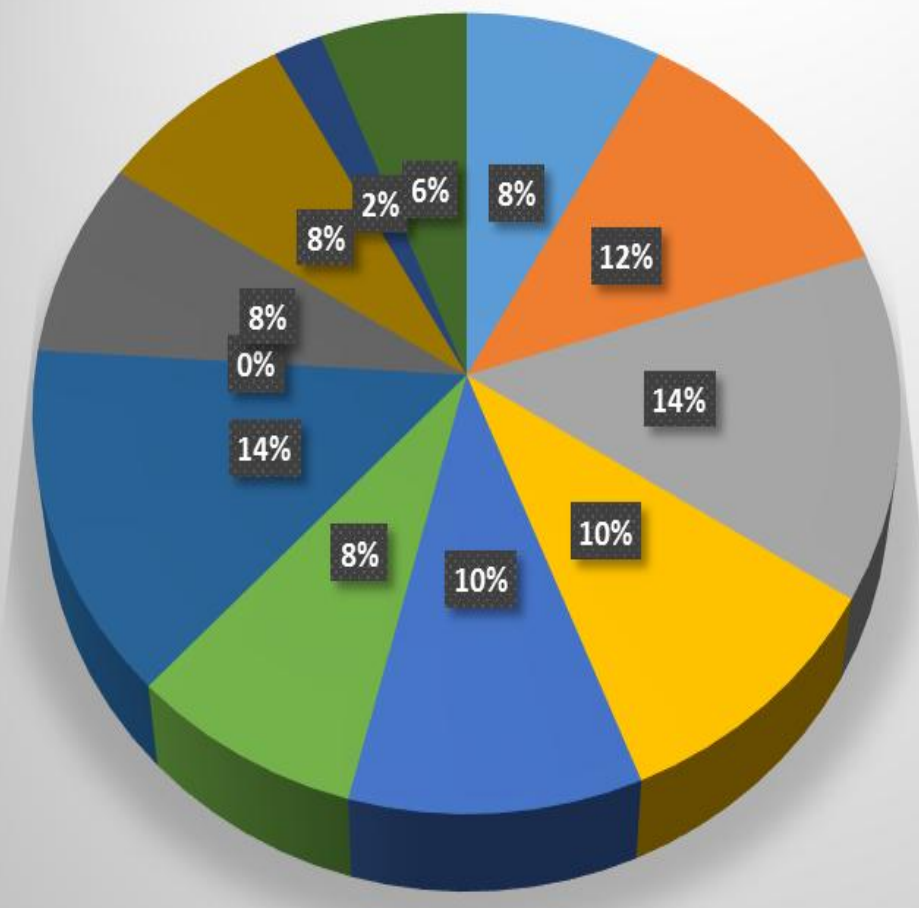

Your presentation is good

Well done

Well organised

- You speak well

- Your speaking is good

- You need more practice

- Presentation was informative

Boring presentation

- Speak loudly

Amicable body language

- Information delivery was organised

- Needs additional data

Figure. 2: Responses from the students on Book Reading Poster Presentation

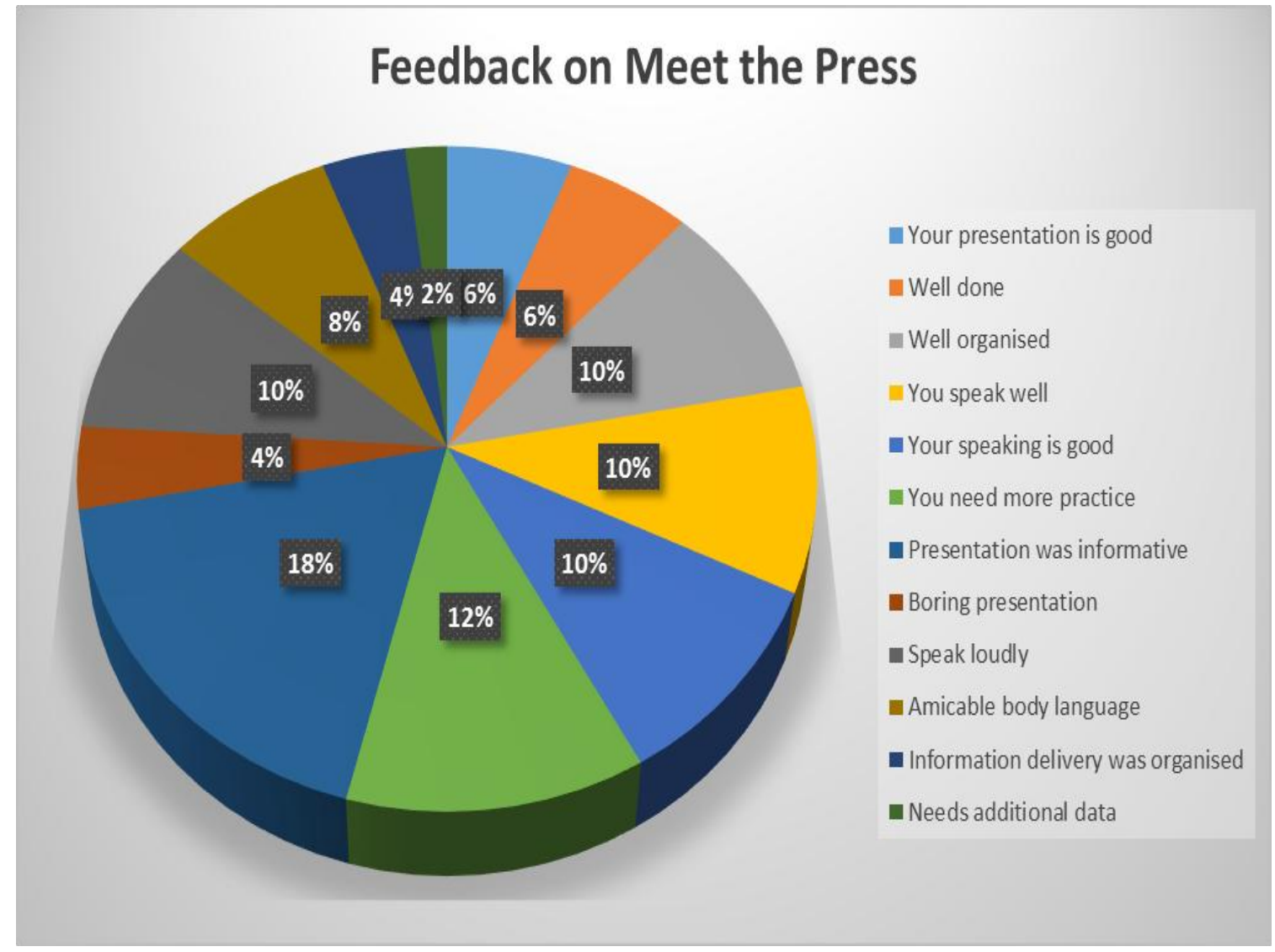

Figure 3: Responses from the students on Meet the Press Presentation 


\section{Feedback on Human Rights Presentation}

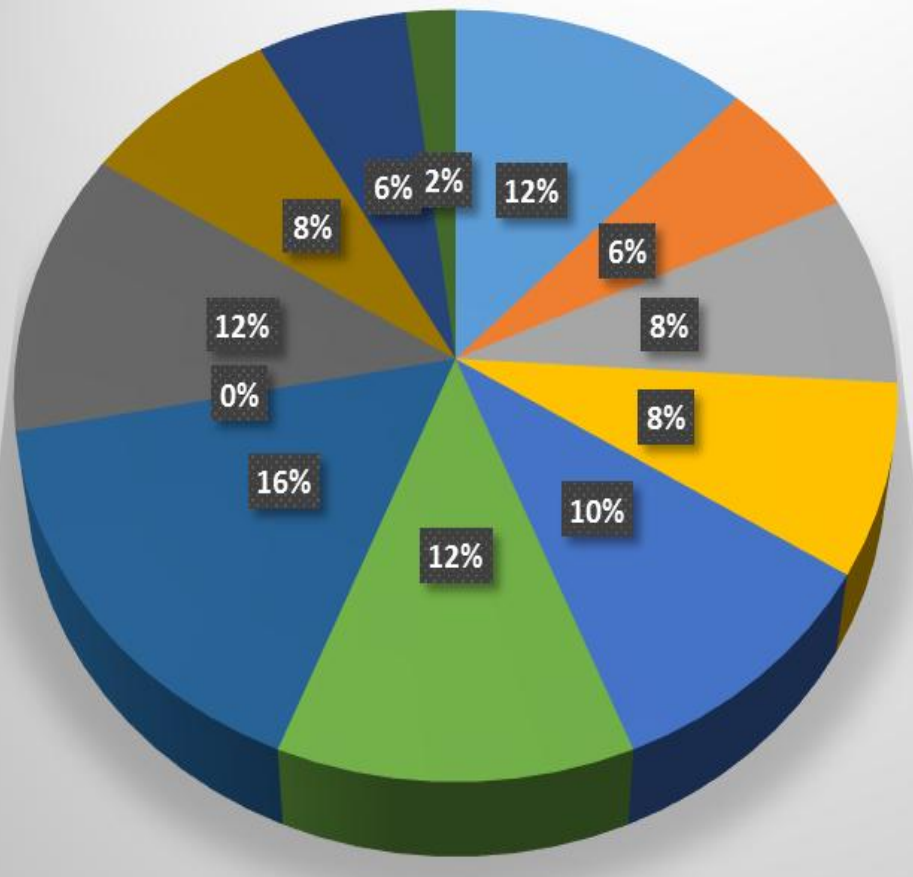

Your presentation is good

Well done

- Well organised

- You speak well

- Your speaking is good

- You need more practice

- Presentation was informative

- Boring presentation

- Speak loudly

- Amicable body language

- Information delivery was organised

- Needs additional data

Fig. 4: Responses from the students on Human Rights Presentation

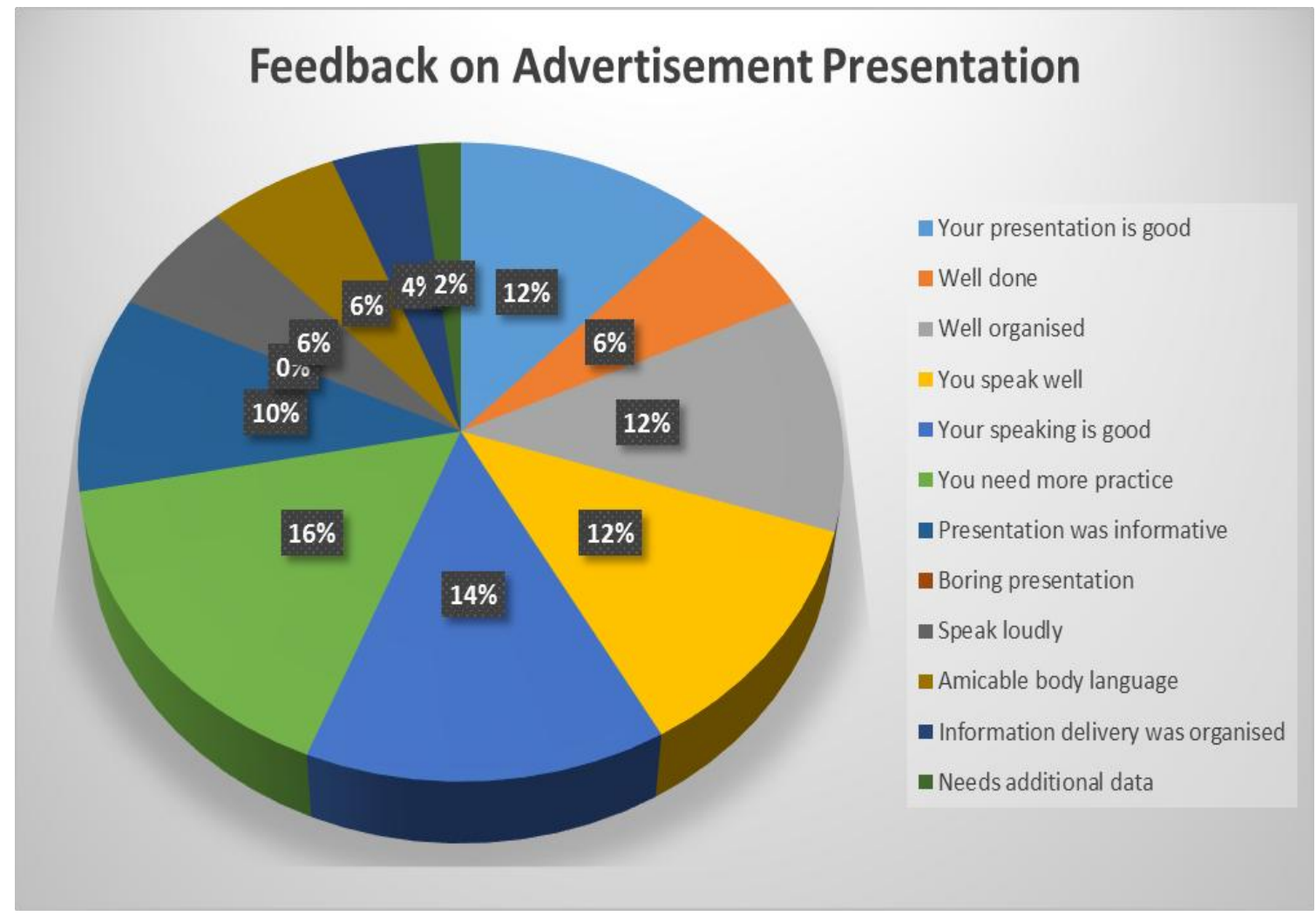

Fig. 5: Responses from the students on Advertisement Presentation 


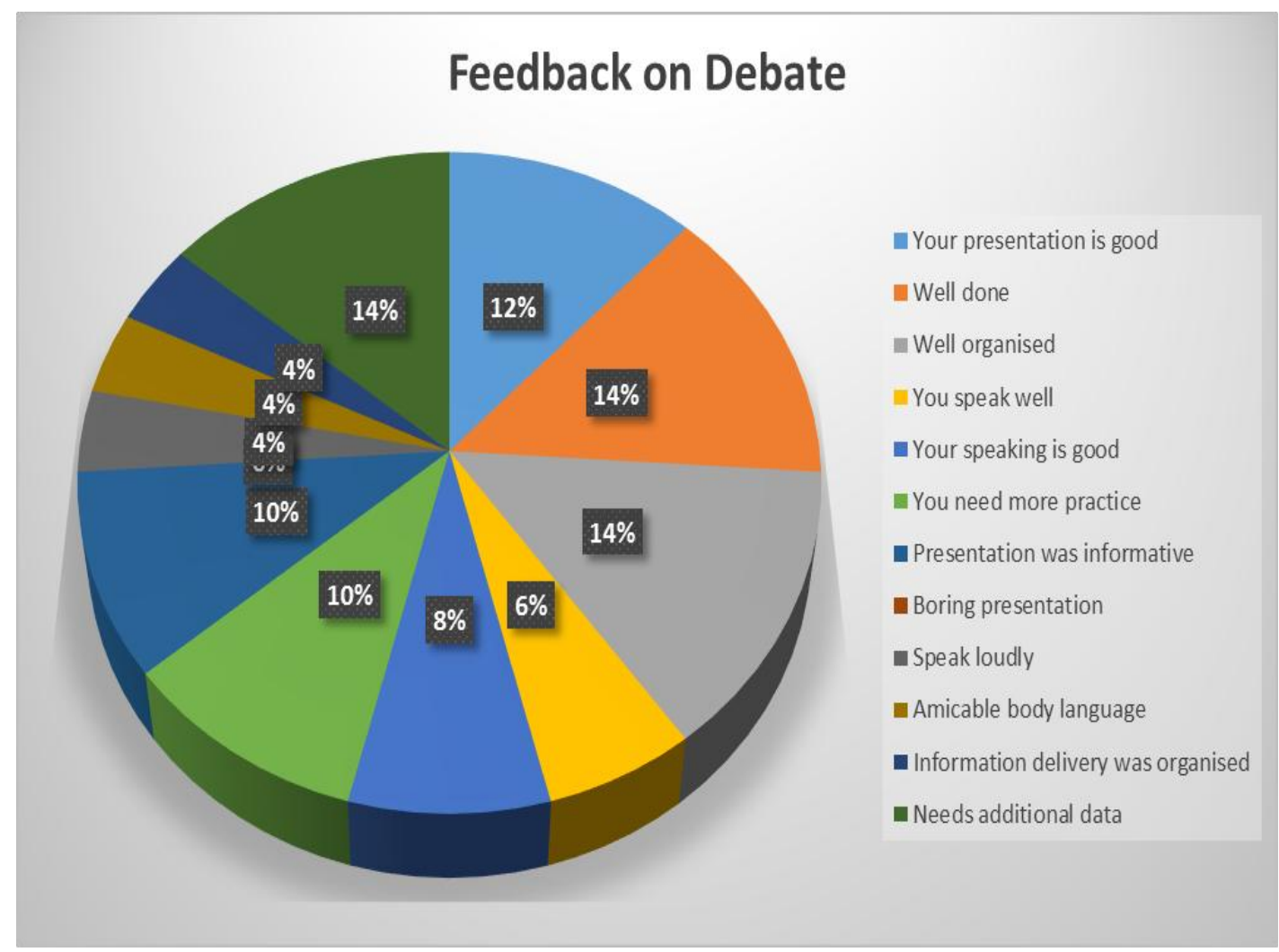

Fig. 6: Responses from the students on Debate

\subsubsection{Teachers' instruction, interaction and role:}

For this phase, we have segmented teachers' instruction, interaction and part into six different categories in total whereas teachers' instruction has been provided in two phases namely 'For the Provider of the Feedback' and 'For the Receiver of the Feedback'. Likewise, interactions have been put into two distinct subparts which are 'T-S Interaction' and 'S-S Interaction'. Lastly, the role of the teachers has been divided into two types like 'As an Observer' and 'As a Facilitator'. For the first part, we have collected the data when students were giving feedback to their peers. At the same time, we have analysed the way the receiver responded while getting feedback. As the graphs (Fig. 1 to 6 ) show, they are just producing some common phrases or sentences; we have addressed these issues as our first priority. We have devised some criteria so that the feedback provider could be of more use for the presenter. Students were provided with checklists before each presentation and the teacher explained each of the criteria so that they could identify the specific areas which have been covered successfully and also the areas that need improvements.

Table 1. Checklist for the peer feedback

\begin{tabular}{|c|c|c|c|c|}
\hline Criteria & I am so impressed & I am happy & It is ok & $\begin{array}{c}\text { Needs } \\
\text { improvement }\end{array}$ \\
\hline Delivery & $\begin{array}{l}\text { I found no problem in } \\
\text { understanding the } \\
\text { starting, development } \\
\text { and closing }\end{array}$ & $\begin{array}{l}\text { I found no problems } \\
\text { in development, } \\
\text { though starting or } \\
\text { closing was not clear }\end{array}$ & $\begin{array}{l}\text { One of the parts } \\
\text { is completely } \\
\text { missing }\end{array}$ & $\begin{array}{l}\text { I could hardly } \\
\text { understand } \\
\text { anything }\end{array}$ \\
\hline Voice & $\begin{array}{l}\text { Voice was clear, audible } \\
\text { and precisely intelligible }\end{array}$ & $\begin{array}{l}\text { Voice was alright } \\
\text { from my part, though } \\
\text { sometimes I had to } \\
\text { concentrate more }\end{array}$ & $\begin{array}{l}\text { Voice was audible } \\
\text { or intelligible, } \\
\text { however I got lost } \\
\text { several times }\end{array}$ & $\begin{array}{l}\text { Somehow } \\
\text { audible voice } \\
\text { but needs } \\
\text { improvement in } \\
\text { intelligibility }\end{array}$ \\
\hline $\begin{array}{c}\text { Body } \\
\text { Language }\end{array}$ & $\begin{array}{l}\text { Body language reflected } \\
\text { his natural presentation } \\
\text { of the language }\end{array}$ & $\begin{array}{l}\text { Body language was } \\
\text { fine, though needs } \\
\text { more attention to } \\
\text { certain aspects like } \\
\text { maintaining eye }\end{array}$ & $\begin{array}{l}\text { Lacks a sense of } \\
\text { body language for } \\
\text { an academic } \\
\text { setting }\end{array}$ & $\begin{array}{l}\text { Almost no } \\
\text { sense of body } \\
\text { language like no } \\
\text { eye contact or } \\
\text { inappropriate }\end{array}$ \\
\hline
\end{tabular}




\begin{tabular}{|c|c|c|c|c|}
\hline & & $\begin{array}{c}\text { contact and proper } \\
\text { gestures }\end{array}$ & & expressions \\
\hline Topic & $\begin{array}{l}\text { The content was } \\
\text { interesting and } \\
\text { presented well by the } \\
\text { use of effective } \\
\text { supporting details }\end{array}$ & $\begin{array}{l}\text { The content was } \\
\text { interesting, however } \\
\text { needs to work on } \\
\text { providing more } \\
\text { supporting details }\end{array}$ & $\begin{array}{l}\text { Some parts of the } \\
\text { topic lack } \\
\text { appropriate } \\
\text { supporting details }\end{array}$ & $\begin{array}{l}\text { Simply a plain } \\
\text { speech or } \\
\text { almost no } \\
\text { supporting } \\
\text { details }\end{array}$ \\
\hline $\begin{array}{l}\text { Connecting } \\
\text { Ideas }\end{array}$ & $\begin{array}{l}\text { Well connected with } \\
\text { appropriate transition } \\
\text { that made the } \\
\text { introduction, body and } \\
\text { conclusion } \\
\text { distinguishable }\end{array}$ & $\begin{array}{l}\text { Transition has been } \\
\text { used, however some } \\
\text { were inappropriate } \\
\text { and in some places } \\
\text { there was none }\end{array}$ & $\begin{array}{l}\text { Transition has } \\
\text { been used only in } \\
\text { some places }\end{array}$ & No transition \\
\hline $\begin{array}{c}\text { Language } \\
\text { Level }\end{array}$ & $\begin{array}{l}\text { Language level was } \\
\text { appropriate for the } \\
\text { context }\end{array}$ & $\begin{array}{l}\text { Language level } \\
\text { needs more attention } \\
\text { in some places }\end{array}$ & $\begin{array}{l}\text { Language } \\
\text { sometimes } \\
\text { became } \\
\text { superficial and } \\
\text { some words did } \\
\text { not fit the context }\end{array}$ & $\begin{array}{c}\text { Language was } \\
\text { completely } \\
\text { inappropriate }\end{array}$ \\
\hline
\end{tabular}

As the students were provided with this checklist, we conducted a short open discussion session to give them specific instructions on what to look at when you are enjoying a presentation. After that, we have also talked about the Dos and DONTs while giving peer feedback.

Table 2. Dos and Don'ts of giving feedback

\begin{tabular}{|c|c|}
\hline \multicolumn{1}{|c|}{ Dos } & Don'ts \\
\hline Scan the information presented & Be sarcastic \\
\hline Concentrate on the content & Make personal comment \\
\hline Stay positive in your tone & Give abstract responses \\
\hline Remain polite and open to criticism & Compare the speaker with someone \\
\hline Be very specific in your words & Make faces while giving feedback \\
\hline
\end{tabular}

At last, students were asked to provide feedback in a controlled setting and based on some situations they were asked to provide effective feedback. To help them, we made them use some significant techniques while giving feedback; for instance, trying to think from the presenter's perspective, pondering over some issues that he might face if he was to give the same presentation and referring to their personal life. Eventually, these techniques helped them in critical thinking, which is a persistent level of thinking that helps students solve problems and reviews the things already done or decisions previously taken (Stratton, 1999). Moore (2007) also adds that by using this ability the thinker improves his own judgment by taking charge of structures and thus bringing certain positive changes in their intellectual principles. We observed that by using their own critical thinking quotient, students could make the use of speaking strategies like Follow-up questions/comments, Turn-taking, Back-channel Cues, Requesting and Giving Clarification and Changing the Subject (Washburn \& Christianson, 1995).

\subsubsection{Challenges and solutions:}

The most prominent issue was that the students have been applying the same stereotypical comments consistently which has fossilised (Han, 2004) their critical thinking quotient. At the same time, while providing the feedback, some students take the ideas and data of the presenter personally and the presenter often take the feedback negatively and does not want to rectify the areas to improve. Moreover, students often expect a positive feedback from the peer and sometimes they take it granted that their peers are not qualified enough to evaluate their work and for this they often show resistance in projecting their work in front of them (Teaching and Learning Development Unit: Peer Assessment and Feedback, 2014). As Barnes, Marcangelo, \& Cartney (2010) upholds, the need for transparent fairness is paramount in this case and 
jugements are not neutralised, there should be some moderation in the process. Keeping their views in mind, we have tried to keep the instructions simple and to some extent, we offered the freedom to the presenter whether he expected the peer feedback in person or in front of the whole class. Also, those who had quandaries regarding receiving peer feedback were given one to one counseling sessions so that they could realize the importance and significance of peer feedback on their speaking. However, there have been some extreme cases where the speaker was completely unwilling to provide or receive feedback and some of them denounced the prominence of peer feedback as they thought that some of their peers were jealous of them and as a result criticised them without no reason. To address these issues, we introduced annonymous feedback at the beginning of the sessions where the feedback provider had to explain the reasons behind his feedback with logical reasoning and any feedback without proper and logical explanation was excluded immediately. This put the students with higher level of anxiety at an ease and afterward they could welcome their peers' feedback in a positive way. Nevertheless, we believe that these are some very common issues which were identified in our context and we are not sure that the same situation may raise in another setting.

\section{METHODOLOGY}

In this paper the theory of Action Research has been applied. Parkin (2009) describes that action research is all about the implementation of certain changes or improvements in particular settings. Winter and MunnGiddings (2001:8) have defined action research to be a 'study of a social situation carried out by those involved in that situation in order to improve both their practice and the quality of their understanding' and it got our attention mostly while conducting this research. As Reason \& Bradbury (2008) describe action research as an approach to design studies to resolve practical problems, therefore we have proposed some techniques in our paper based on our observation. Moreover, Hopkins (2002) believes that the action research can be termed as a practical act as well as a research procedure which is an act controlled by questions and efforts to find out solutions through understanding. Meyer (2000) asserts that it is rewarding in solving practical problems and motivating the researchers which involve them into applying solutions. For instance, in O'Leary's model (2004), it is stressed that 'cycles converge towards better situation understanding and improved action implementation; and are based in evaluative practice that alters between action and critical reflection'. He has taken action research as an 'experiential learning approach' and it encompasses observation, reflection, planning and act as the four basic steps in a cyclic and repetitive order (Fig. 7). Furthermore, he proclaims that it is a continuous process linking data collection, refining the methods and interpretation all together to observe the developments in the situation.

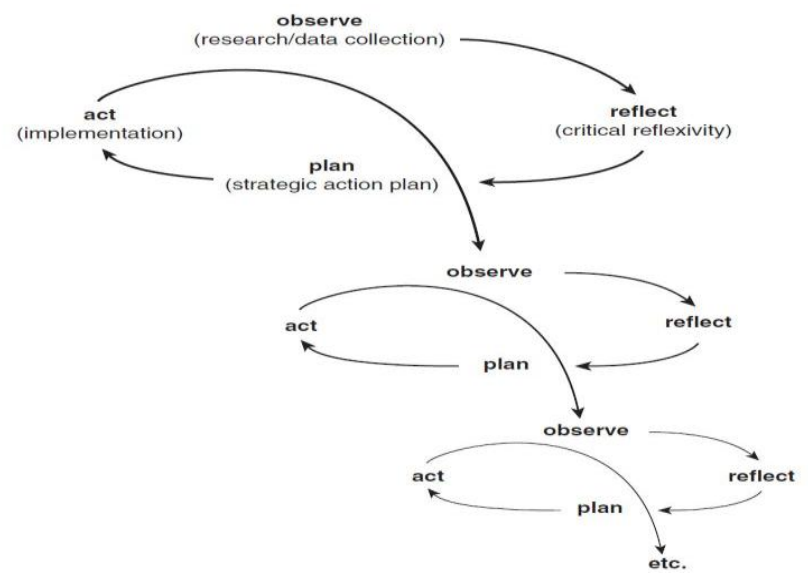

Fig. 7: O'Leary's cycles of research (adapted from Koshy, Heather, \& Valsa, 2010)

Later on, this method was adapted by Stephen Corey for conducting research on educational issues. In addition, Whitehead \& McNiff (2005) uphold that the action research has long been an unappreciated one whereas it can contribute to a great extent in understanding and managing the resources in practice. For our paper, an action research approach based on Lewin (1946) was adopted. Waterman et al. (2001) maintain that in this approach, both qualitative and quantitative research methods are applied which can be taken as corresponding to each other. Carr and Kemmis (1986:164) include the fundamental principles of the action research which are 'participatory character, democratic impulse and simultaneous contribution to social science (knowledge) and social change (practice)'. Action researchers 'engage in careful diligent enquiry not for the purpose of discovering new facts or revising accepted laws or theories, but to acquire information having practical application to the solution of specific problems related to their work' (Stringer, 2004: 3). As from our part, through our observations, we have noticed that the students often fail to come up with constructive feedback to their peers as they lack in the deep understanding of the situation that may raise 
after their ineffective feedback, both for him or for the peer. However, as the students are not using their critical reasoning quotient while providing feedback to their peers, the receiver and the provider both suffer. For this, in this paper, we have devised some techniques which can be used before evaluating a speaker's skills in specific ESL context, for example, specific instructions and checklists. As a part of our Action Research, at first, we have collected qualitative data of the oral feedback to be used as sample peer feedback from the students of ENG091 and ENG101 courses through interviews and observations. After that, the data has been analysed using Multivariate Analysis (Hair et al., 1995). Based on the analysis, we have attempted to provide some guidelines for the students and these guidelines addressed the specific problems they face while giving feedback to their peers. Furthermore, we divided our instructions into some categories so that both the provider and the receiver can be benefitted and as a result of the process, the critical reasoning quotient of the students get developed. To add more, we have been facilitating the whole process, from the very beginning till the end, to ensure a successful outcome and to assess the effectiveness of the instructions. At last, we have collected students' feedback through questionnaire survey and have represented the research findings through a Pie Chart at the end of the research paper.

\section{RESULTS}

As per the techniques and instructions, students were asked to provide feedback for the second time. This time they were strictly prohibited to violate any guideline for giving effective feedback. To ensure the best outcome, we have repeated the same process for the first three presentations (News Report, Book Reading Poster Presentation and Meet the Press) which could address their cognitive process through 'meaningful drills' (Paulson \& Bruder, 1976). After the first three presentations, students were told to provide effective feedback without the checklist and prior instruction. The result was visible to a great extent as they could provide effective feedback to their peers and also managed to bring forth some issues which incapacitated their own presentations. At last, a short questionnaire survey form was given to them to collect data on the outcome of the instructions. Their feedback is shown through Fig. 8.

Fig. 8: Students' responses after the implementation of the strategies

\section{Students' Feedback after the Implementation of the Strategies Presented}

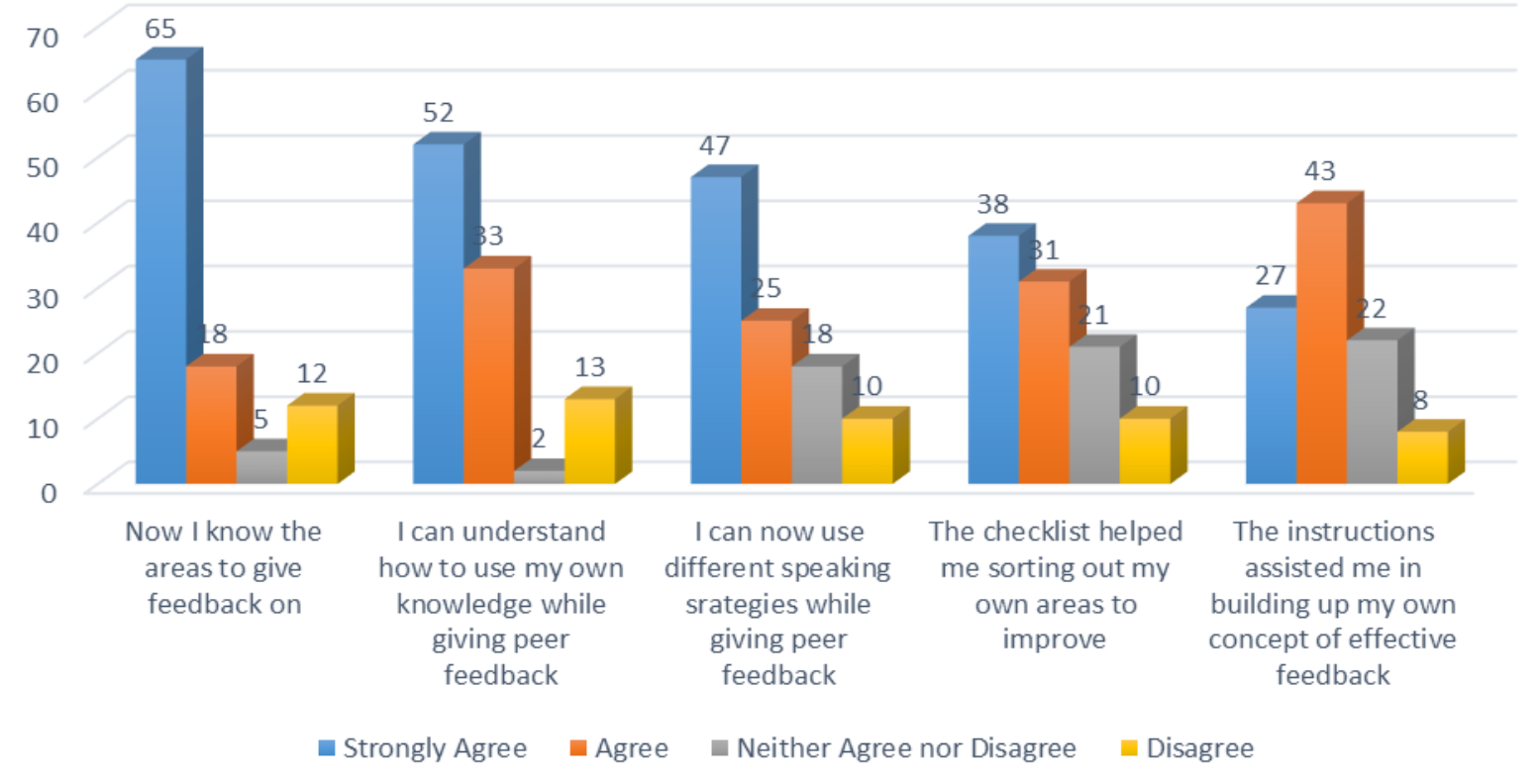

\section{CONCLUSION}

As feedback has played a significant role in the academic success of the students constantly, we have attempted to put forward some techniques of peer feedback which is a remarkable part of feedback. Peer feedback proves to be fruitful in terms of developing students' critical thinking ability and thus making them realise the importance of several speaking strategies. Once done appropriately, these techniques can also help a student put himself in someone else's place and sort out own areas to improve. Nevertheless, we have applied these techniques in an ESL setting in a smaller scale. On our part, we would be satisfied if this 
research can contribute to the development of learning styles and thus assist the future researchers. Our acknowledgement also goes to those writers who had undertaken some noble tasks and for their noteworthy support, we could gather necessary information. By the grace of the Almighty, in future, we would like to conduct another research on giving effective peer feedback for writing. In conclusion, we would like to express our heartfelt gratitude to our students who showed a sign of deep endurance throughout the whole process of our research.

\section{REFERENCES}

Barnes, C., Marcangelo, C., \& Cartney, P. (2010). Contemporary issues in assessment in health sciences and practice education. Opportunities offered through self, peer and group assessment. In The opportunities and challenges of self, peer and group assessment. London: Health Sciences and Practice Subject Centre.

Carr, W., \& Kemmis, S. (1986). Becoming Critical: Education, Knowledge and Action Research. London: Falmer.

Dweck, C., \& Bush, E. (1976). Sex differences in learned helplessness: (I) Differential debilitation with peer and adult evaluators. Developmental Psychology, Vol 12 (2), 147-156.

ENG 091: Foundation Course in English (Non-credit). (2014). Retrieved from BRAC Institute of Languages: http://bil.bracu.ac.bd/courses/undergraduate-english-courses/eng-091-non-credit

ENG 101: English Fundamentals (3 credits). (2014). Retrieved from BRAC Institute of Languages: http://bil.bracu.ac.bd/courses/undergraduate-english-courses/eng-101

Glasson, T. (2009). Improving Student Achievement: A Practical Guide to Assessment for Learning. Carlton South: Curriculum Corporation.

Goldrick-Jones, A., \& Mossman, T. (2014, October 20). How to Give Effective Peer Feedback. Retrieved from Prezi: https://prezi.com/-zzgxojfvrnu/how-to-give-effective-peer-feedback/

Hair, J. J., Anderson, R., Tatham , R., \& Black, W. (1984). Multivariate Data Analysis (4th edition 1995 ed.). Englewood Cliffs: Prentice-Hall.

Han, Z. (2004). Fossilization in Adult Second Language Acquisition. Multilingual Matters.

Henry, S. E., Medway, F. J., \& Scarbro, H. A. ( 1979). Sex and locus of control as determinants of children's responses to peer versus adult praise. Journal of Educational Psychology, Vol 71 (5), 604-612.

Hopkins, D. (2002). A Teacher's Guide to Classroom Research. Maidenhood: Open University Press.

Hyland, K., \& Hyland, F. (2006). Feedback in Second Language Writing: Contexts and Issues. New York: Cambridge University Press.

Jacobs, G. M., Curtis, A., Braine, G., \& Huang, S.-Y. (1998). Feedback on student writing: Taking the middle path. Journal of Second Language Writing, 7(3), 307-317.

Koshy, E., Heather, W., \& Valsa, K. (2010). Action Research in Healthcare. SAGE.

Lewin, K. (1946). Action research and minority problems. J Soc. Issues 2(4), 34-46.

Mangelsdorf, K. (1992). Peer reviews in the ESL composition classrooms: what do the students think? ELT Journal 46, 274-284.

Meyer, J. (2000). Using qualitative methods in health related action research. British Medical Journal.

Moore, D. T. (2007). Critical Thinking and Intelligence Analysis. Washington, DC: DIANE Publishing.

Obah, T. (1993). Learning from others in the ESL writing class. English Quarterly, 25, 8-13.

O'Leary, Z. (2004). The essential guide to doing research. Sage.

Parkin, P. (2009). Managing change in healthcare using action research. London: Plagrave.

Paulson, C., \& Bruder, M. (1976). Teaching English As a Second Language: Techniques and Procedures. Cengage Learning College.

Peer feedback. (2014). Retrieved from Assessment for Learning:

http://www.assessmentforlearning.edu.au/professional_learning/peer_feedback/peer_feedback_landi ng_page.html 
Reason, P., \& Bradbury, H. (2008). The SAGE Handbook of Action Research: Participative Inquiry and Practice (2nd edition). London: SAGE.

Shafaei, A. (2011). Frontiers of Language and Teaching. Proceedings of the 2011 International Online Language Conference (IOLC 2011).

Stratton, J. (1999). Critical Thinking for College Students. Maryland: Rowman \& Littlefield.

Stringer, E. T., \& William, G. (2004). Action Research in Health. Merrill Prentice Hall.

Teaching and Learning Development Unit: Peer Assessment and Feedback. (2014, December). Retrieved from University of Sussex: http://www.sussex.ac.uk/tldu/ideas/assessment/peer

Topping, K., \& Ehly, S. (1998). Peer-assisted Learning. Lawrence Erlbaum Associates.

Tsui, A. B., \& M., N. (2000). Do secondary L2 writers benefit from peer comments? Journal of Second Language Writing, 9 (2), 147-170.

Washburn, N., \& Christianson, K. (1995). Teaching Conversation Strategies Through Pair-Taping. TESL Reporter.

Waterman, H., Tillen, D., Dickson, R., \& de Koning, K. (2001). Action research: a systematic review and assessment for guidance. Health Technology Assessment 5(23), 1-166.

Whitehead, J., \& McNiff, J. (2005). All You Need To Know About Action Research. London: SAGE.

Winter, R., \& Munn-Giddings, C. (2001). A Handbook for Action Research in Health and Social Care. London: Routledge. 